\title{
Flirting with Photography: Henry James and Photographic Exchange
}

\author{
Owen Clayton
}

Like many authors of the long nineteenth-century period, Henry James was both fascinated and troubled by photography's capacity to extend social relations across distance and time. As this article will show, in The Awkward Age (1899) and 'Crapy Cornelia' (1909) he represents photography as enabling new forms of virtual flirtation. The Awkward Age projects its protagonist, an adolescent girl named Nanda, into a network of photographic exchange. This leads to serious problems when her mother seeks to win Nanda a suitor. The text not only depicts photographs as modes of flirtation; it also shares with photography a concern for deixical signification. The book presents the identity of its individual characters through a blank writing style that is both flirtatious and photographic in its pleasurable deferral of meaning. By the time he wrote 'Crapy Cornelia', James had adjusted to the new instantaneous and portable photography. As a result, this later story portrays obsolete carte-de-visite photography in nostalgic terms: as a form that enabled affective (and effective) networks of connection, even between the living and the dead.

Keywords: Henry James (1843-1916), flirtation, photography, networks, photographic exchange, William Dean Howells (1837-1920), photography-as-network, portraits, The Awkward Age, 'Crapy Cornelia' 
At the beginning of William Dean Howells' short story, 'The Magic of a Voice' (1899), a man known as Langbourne finds himself unable to sleep because of a loud conversation that is coming through the wall of an adjacent hotel room. He begins to listen, becoming enraptured even though he cannot quite make out what the two speakers, both young women, are saying. 'Eavesdropping with all his might', he becomes besotted with one of the women, whose voice possesses 'imagination and humour which could charm with absolute control' (225). Sleeping until late the next morning, he finds that the two ladies have left. In one of many dubious actions that he undertakes in this story, Langbourne enters their vacated hotel room and finds a letter with a nursery circular, on which is printed a list of seeds. As the name on the envelope is Barbara Simpson, Langbourne convinces himself that it is her voice with which he has fallen in love. Never having seen Miss Simpson's face, he builds up a mental picture of her to match the voice he had heard the previous evening. Returning the circular by post, Langbourne receives a note of thanks. From these seedy beginnings, the letters grow into a flirtatious conversation with the eligible Miss Simpson. As the correspondence becomes more intimate, the pair exchange photographs. The portrait that Miss Simpson sends shows a face 'so far averted that Langbourne could get nothing but the curve of a longish cheek' (237). A proto-Barthesian believer in photography's indexical qualities, Langbourne convinces himself that 'the photograph had confirmed him in its evasive fashion at every point of his conjecture concerning her. It was the face he had imagined her having, or so he now imagined' (238). As the circuitous syntax of this latter sentence suggests, all is not quite what it appears.

When the two characters eventually meet, the ease of their epistolary discourse vanishes, replaced with polite small talk punctuated by long silences. As if having once shared a one-night stand, they feel a pained sense of awkwardness at 'the anomaly of their having been intimates without being acquaintances' (248). Their unease is exacerbated by a 
revelation that the image was in fact a picture of Miss Simpson's close friend, Juliet Bingham, which was sent as a private joke between the two women. In several ways that bear relevance to my following discussion of Henry James, this sequence of events is emblematic of the cultural position of late nineteenth-century photography. First, it dramatises some of the cultural concerns felt by many turn-of-the century authors at the propriety of a technology that could create intimate strangers. Second, the image suggests that with photography comes a separation of the body from the appearance of the body: it is a visual mode in which the former is not guaranteed by the latter. Third, the fact that the image is of the wrong person exemplifies a widespread belief that photography threatened to homogenise its subjects, rendering them interchangeable. Virtual flirtations of the kind described by Howells risked becoming public affairs, potentially open to any and all viewers. As this example suggests, many late Victorian writers understood that photographs are open to re-use and reinterpretation — that they are, in this sense, always-already public documents. ${ }^{1}$

This article will examine each of these elements in relation to depictions of photography and flirtation by Howells' friend and contemporary, Henry James, whose writing is flirtatious in ways that parallel photography's distanced intimacy. I will examine the novel The Awkward Age (1899) and short story 'Crapy Cornelia' (1909), two of James' later works in which networks of flirtatious photographs play a prominent role. Photographic exchange forges relationships across time and space in both texts, creating virtual (but very real) flirtations that titillate and endanger participants. ${ }^{2}$ The Awkward Age presents a world in which easily-portable photographic technology, most obviously the Kodak, was still in the process of achieving cultural dominance. In this novel the meaning of different photographies remains in flux. By contrast, in 'Crapy Cornelia' modern photography is assumed to have crystallised into a single medium whose qualities are portability and instantaneity. The story 
thus idealises the very different carte-de-visite photographs of the 1860 s in picturesque terms: a beautiful but obsolete form, the carte becomes a nostalgic metonym for a simpler era.

A transitional text in James' career, The Awkward Age adopts a blank (or 'flirtatious') writing style in which language is evacuated of individual consciousness and definite meaning. His deictic prose is not caused by photography, but the text does share with photography a concern for the way in which meaning is context-dependent, even in supposedly-straightforward exchanges of information. The Awkward Age is indexical, not in the sense of pointing to its signified, but rather in providing both the guarantee of meaning and its failure. This aspect of the novel troubles Victorian notions of individual identity, since the characters signified by James' writing are often uncertain, dependent on non-linguistic clues such as gesture or tone of voice. Vacillating between definite and deferred communication, the text's narrative voice is not the voice of a single individual but rather that of a collective, of a network of interpersonal relations. For the later James, as Sharon Cameron notes, 'consciousness is not in persons; it is rather between them'. ${ }^{3}$ A particularly visual and visible tele-technology, photography is a potent figure for the Jamesian networked consciousness. $^{4}$

Critics have emphasised how uncomfortable James felt having his picture taken. Julie Grossman connects what she calls his 'scopophobia' with an 'anxiety about becoming publicly exposed'.5 Discussing homoeroticism in James' autobiographical writings, Laura Saltz argues that 'The apparent evacuation of consciousness' of the subjects of photography is 'what disturbs James most about them'. For Saltz, 'James's fear of exposure, at one level, is an anxiety that his queerness might be discerned by the eye of man and camera'. ${ }^{6}$ Building on this work, I want to suggest that James was concerned with photography not only for personal and psychological reasons, but also because of his feeling that it was changing relations between people more generally, especially in the realm of flirtation. 
James' work has been compared to photography and hailed for its proto-modernism. ${ }^{7}$ For Ralph Borgardus, for example, James 'possessed a photographer's eye and mode of working' ${ }^{8}$ According to this view, James' work provides insight into the intense psychological meaning that human beings can invest in small moments, such when the eponymous bowl is smashed in his novel The Golden Bowl (1904). Typical of much literary scholarship that discusses photography, Borgardus assumes that the medium's essence is instantaneity and that its highest expression can be found in modernist art photography. ${ }^{9}$ Following this lead, subsequent criticism has associated James' representations of photography, as well as his photographic style, with his proto-modernism. As a result, critics have often suggested that he saw photography as an aesthetic rival, one which he needed to denigrate in comparison with his practice as a writer. ${ }^{10}$

Yet photography played many roles in James' life and work, and not always as a source of artistic jealousy. He was, for example, attracted to the process of exchanging photographs: a process that he initiated in his personal life with almost every new friendship that he made. ${ }^{11}$ These exchanges could be erotically charged, especially when the older James swapped photographs with younger men. In a 1906 letter to Hendrik Anderson, for instance, he wrote: 'I look your kodaks (as I suppose them) over again, while I write and they make me groan, in spirit, that I'm not standing there before the whole company with you.' ${ }^{12}$ To foray into psychobiography briefly, it is clear that there was a tension between James' desire to possess images of others and his worry that he himself was going to be made visible. His lifelong obsession with control finds its clearest outlet and its strongest antagonist in photography, a form which enabled the collection of images by him but also the public dissemination of images of him. More generally, James was conscious that the increased circulation of photographs at the end of the nineteenth century represented a shift towards a society in which exposure, in the dual meaning of that term, was becoming routine. 
In the following section, I provide a brief theorisation and cultural history of flirtation, noting some of the ways in which photography enables its extension beyond a person's immediate physical surroundings. I will then discuss James' early representations of flirtation. Unlike in his later work, the early James does not represent photography as a form of flirtation, but rather as an excuse for it.

\section{Flirtation, Photography, and the Early James}

Flirtation's liminality has made harder to theorise than its more definite cousin, seduction. As a result it has been downplayed in Western philosophical, sociological and psychological discourse. In an essay entitled 'Thoughts for the Times on War and Death' (1915), for example, Sigmund Freud compared what he called 'American flirtation' to a 'continental love-affair', a comparison in which flirtation comes off badly. As the term 'American flirtation' suggests, Freud associates this mode of being with the United States, a nation which he famously claimed not to hate but rather to regret. In flirtation, he claims, 'it is understood from the beginning that nothing is to happen'; this means that the participants risk nothing, leaving the activity 'hollow and empty'. Seduction, in contrast, carries 'serious consequences' and so, like the inevitability of death, forces its subjects to recognise what is truly important — in effect, to live fuller lives. ${ }^{13}$ Freud raises flirtation in order to dispense with it and to move onto more 'serious' subjects: the war and death of his title.

In contrast to Freud, Georg Simmel gave flirtation sustained attention in two publications of the early twentieth century. In his work Simmel argues that flirtation emerged as the paradigmatic form of social relation within modernity, especially in the metropolis. ${ }^{14}$ While Freud sees flirtation as a poor imitation of seduction, Simmel claims that it is a distinct mode in its own right. For him, flirtation is empowering for women, whom he 
problematically positions as being the inevitable instigator of flirtation. There is great pleasure to be taken in flirtation, which he characterises in Kantian terms as 'purposiveness without purpose'. ${ }^{15}$ By applying Immanuel Kant's famous definition of fine art to flirtation, Simmel implies that flirtation is itself an art: a realm in which participants are set free to play, rather than one in which they seek to establish fixed rules or to determine ontological certainty. Flirtation's 'purposiveness' puts it at odds with science; lacking a telos, its aims are in opposition to the Enlightenment search for rational meaning. This opposition is imperfect, however, as Simmel's Kantian language might suggest. Flirtation cannot lead anywhere definite or else it becomes seduction, yet it can, and often does, lead exactly to just such an outcome. Flirtation is, then, a mode of absolute uncertainty, not only in the attitude that its participants take to each other, but in its opposition to seduction, a mode which it threatens to, but does not inevitably, become.

According to Adam Phillips, flirtation is a form of behaviour in which 'the known and wished for end is being refused, deferred or even denied'. ${ }^{16}$ As such, it is particularly well suited to photography. Fluctuating between intimacy and distance in a way that parallels the act of flirtation, photographs are of the person depicted but they are also not that person. These images operate, or are believed to operate, via a silent language of the body. Similarly, as Paul Fleming argues, to flirt is to be primarily concerned with gestures, in contrast to expressing love, which has a complex set of lexical rules. ${ }^{17}$ If this is the case, then visual media such as photography are able to extend flirtation beyond a person's immediate surroundings without running the risks associated with seduction. A good example is the nineteenth-century portrait photograph, which, as in Howells' 'The Magic of a Voice', became a common mode by which virtual flirtations could take place. Looking at these images could be an intimate experience, since portraits are typically small objects that can be held in the hands, looked at closely and intensely, and carried close to the body. This is a 
particularly flirtatious situation for those, like Langbourne, who believe in photography's purported indexicality.

Henry James was fascinated by flirting. His early novel Daisy Miller (1878-79) reads like a test-case of Freud's 'American flirtation': a tale of an innocent New World flirt who is caught up amid an older and more serious world of European seduction. Photography is absent from this story as a medium for flirtation, however, since James had not yet connected the two. As I will now discuss, in one of his next published works, the short story 'Four Meetings' (1879), he does show photography and flirtation occurring together, though here, unlike in later texts, they remain distinct activities.

'Four Meetings' opens with a scene of a New England tea-party, during which an unnamed male narrator shows photographs of picturesque tourist sites in Europe to a young woman named Caroline Spencer. Though she is described by the hostess as someone who 'doesn't care for flirting', the narrator feels an intense attraction to Miss Spenser during the time that they spend looking over the images. ${ }^{18}$ Not interested in chasing young men, the innocent Miss Spencer simply and earnestly wishes to visit Europe. Yet while looking over the generic images, 'large views of Switzerland, Italy and Spain, landscapes, reproductions of famous buildings, pictures and statues', her cheeks flush in a way that the narrator associates with flirting (3). 'She looked', he states, 'as pretty as if instead of showing her photographs I had been making love to her' (5-6). ${ }^{19}$ This conflation of photographic tourism with the acknowledgement of sexual desire is, the story implies, dangerous for young women because it can lead them to make foolish decisions that invite scandal.

The narrator meets Spencer again in Europe, at which point she has been abandoned by a dissolute cousin, having lent him money on the unlikely promise that he would pay her 
back. She later takes in her cousin's wife, who claims to be an impoverished French countess, but whom the narrator suspects may be 'the runaway wife of a too-jealous hairdresser or of a too-morose pastry cook... or even...some character, of the nomadic sort, less edifying still' (38). The narrator refuses to reveal these suspicions to Miss Spencer: 'I couldn't let in, by the jog of a shutter, as it were, a hard informing ray and then, washing my hands of the business, turn my back for ever' (38). On one level, this 'hard informing ray' suggests the supposedly hard truths of realism, a literary school to which James was dedicated in his early period. The reader might thus see this clichéd photographic metaphor as an early intervention in the 'Realism Wars', an aesthetic conflict between literary realists and romanticists that came to prominence in the United States during the 1880s. This interpretation makes sense, since the story presents Spencer's inability to see the truth about her cousin or the French countess as being the result of romantic delusions, delusions which sit in contrast to the early James' realist form of writing. The fact that tourist images initiate her fantastical dreaming aligns photography with the damaging effects, as James understood them at this time, of Romance novels. Yet James only added this reference to photography into his much longer, 1909 version of 'Four Meetings', which was published as part of the New York Edition collection. In fact, the reference to 'the jog of a shutter' is anachronistic to the story's 1870s setting, implying as it does the mechanisms of instantaneous exposure most commonly associated with Kodak photography. ${ }^{20}$ The addition of this reference enhances the narrative's retrospective atmosphere: the feeling that the story is in the very recent past. It also indicates the extent to which, by the turn of the century, the author saw photography as a prominent and troubling form of virtual network. Specifically, as I will go on to discuss, he saw it as turning flirtation into the default form of modern social relation.

According to Patriza Di Bello, by the 1860s photography was 'associated with providing men and women occasions for flirting, playful courting and expressing sentimental 
bonds and affections'. ${ }^{21}$ At first such uses were restricted to the upper orders, though they broadened out to the middle-class in following decades. In his later work James moved away from the simplistic Romance-Realism binary discussed above, but he retained his earlier sense that photographic exchange was a dangerous influence on the desires of young people. Giving and receiving portraits might, in his view, be a way of engaging in illicit sexual activities from which the protagonists feel emotionally and morally detached. As the following section will show, these fears increased as he began to see photographs not only as a means by which flirtation might occur, but as forms of flirtation in themselves. ${ }^{22}$

\section{Photography as Flirtation in The Awkward Age}

Since a flirting photographed subject must engage with a camera, the flirtation that is produced has no determined recipient and no ultimate end point. As nodes in a wider network, the subjects of photography, whether flirting or not, risked losing their traditional status as sovereign and unique individuals, even while photography appeared to provide empirical evidence for their personhood. These apprehensions emerge in James' The Awkward Age in two ways. First, on the level of content, the text dramatizes the potential dangers of such limitless expansion for its characters, specifically for the young Nanda, who is rendered sexually available (and thereby spoiled) through photography. Second, on the level of form, the book enacts a photographic (or 'photographic') blurring of identity through its deictic writing style and flirtatious deferrals of meaning. In making these two claims, which I will pursue in both this and the following section, my analysis departs from the Art Historical concerns that have dominated literary scholarship on James and photography. 
The Awkward Age opens with a conversation in which an elderly man, Mr. Longdon, and a younger one, Mr Vanderbank, discuss a picture that the latter has been given by an adolescent girl, Nanda:

Mr. Longdon had gone to the place-little Nanda was a glazed white wood. He took her up and held her out; for a moment he said nothing, but presently, over his glasses, rested on his host a look intenser even than his scrutiny of the faded image. "Do they give their portraits now?"

"Little girls—innocent lambs? Surely, to old friends. Didn't they in your time?"

Mr. Longdon studied the portrait again; after which, with an exhalation of something between superiority and regret, "They never did to me," he returned.

"Well, you can have all you want now!" Vanderbank laughed.

His friend gave a slow, droll head-shake. "I don't want them 'now'!"

"You could do with them, my dear sir, still," Vanderbank continued in the same manner, "every bit $I$ do!"

"I'm sure you do nothing you oughtn't." 23

The sexualized nature of this conversation is fairly straightforward. It revolves around the propriety of a young woman giving away her image and what the young man who has her picture might use it for: that is, for masturbation. As a networked object, the photograph gains a haptic potential, and by extension so does Nanda herself. Susan Mizruchi argues that 'James' photographs of adolescent females' represent 'the mastery and exchange of female commodities', while Michèle Mendelssohn claims that Nanda's photograph illustrates the novel's concern with adult 'erotic mastery' over children. ${ }^{24}$ Though the image is certainly part of a system of commodity exchange, Mr. Longdon is unsure how to read the photograph, which suggests that he is not entirely the master, to use a Jamesian term, of this situation. He is unsure whether Nanda is an innocent lamb — solely a passive, commodified victim, or whether, perhaps more shockingly still, she is flirting with the camera and is, therefore, complicit in her own commodification. Either way, she is certainly not empowered through 
flirtation in the manner that Simmel might suggest. Even if she is innocent of conscious flirtation, which would certainly be Longdon's preference, his broader concerns arise from the question of whether it is proper to give away an image of one's self that might be used for things they 'oughtn't'.

Disseminating images strikes Longdon as a potentially lewd act, one which he finds difficult to balance with Nanda's youth and inexperience. Photographic reproducibility alarms him: Vanderbank, in his view, possesses 'too many photographs' (7). He is tormented by a fear that Nanda's photograph, like those of Verena Tarrant in James' The Bostonians (1886), might get into the hands of any person willing to pay for or exchange them. Yet there are layers of ambiguity in his response: did young girls give portraits to others in his time, carte-de-visites for example, but not to him? Or have social mores changed along with the improved printing technology? Furthermore, as his 'exhalation of something between superiority and regret' and claim that he does not want the images 'now' both suggest, he appears to regret the change to a less conservative attitude to the giving and receiving of images, but also to be jealous of Vanderbank receiving such photographs. His claim not to want such pictures ' $n o w$ ' is another deferral, a self-conscious rejection that contains the possibility of flirtation within it, since it suggests that his younger self may have accepted Nanda's photograph. Despite these ambiguities, Longdon presents himself as the embodiment of what Vanderbank calls a 'better tradition' (17). This is an older form of social relation in which codes of decency, modesty and politeness were more dominant than they are during the 'awkward age' of the novel's title, an era which one of the characters refers to as 'the end of everything' (190). As his name indicates, Van is at the forefront of this new social world, at ease within what Mrs. Brook calls 'morbid modernity' (66). ${ }^{25}$

The Awkward Age's primary concern is the status of young women who are on the brink of coming out into society - who are, as the title also suggests, at an awkward age. 
The novel asks whether it is better to be brought up among adult conversation, as Nanda is raised, or whether to be sheltered from all potentially scandalous or salacious talk, as in the case of her friend, Aggie. In an evocative phrase, Nanda's mother, Mrs Brookenham (informally referred to as Mrs Brook), declares 'the whole question of bringing girls forward or not. The question of-well, what do you call it? - their exposure. It's the question, it appears - the question of the future' (161). As Pamela Thurschwell notes, the book's repeated references to exposure connote the common (though not universal) nineteenth-century belief that photography 'allowed for an uncanny indexical relation to past selves in the present moment; letting people view themselves and others, as young and new, even when they were no longer either' ${ }^{26}$ Acknowledging that she has chosen to bring Nanda out into the light of society, and presumably also to allow her to exchange photographs, Mrs. Brook states that 'Nanda, of course, is exposed...fearfully' (161). This 'fearfully' implies the tensions involved in her decision to allow Nanda to be exposed. On the one hand, her fear relates to the sexual vulnerability associated with Nanda coming out, to her daughter's availability on the market and the possibility of rejection that this implies. On the other hand, it is an anxiety about being perceived as a filial exhibitionist, of exposing Nanda in a way that contemporaries might view as unseemly. Both concerns stem from the transitional state of turn-of-the-century British society, in which moral codes appear to be loosening, but in no deliberate, linear or consistent manner.

Concomitant with this cultural shift was the willingness of late Victorian society to embrace photographic exchange. The Awkward Age captures the anxieties of a society that was beginning to see photography as a hegemonic cultural force. It stages these anxieties through humour and paradox. Towards the end of the novel, for instance, when Nanda is preparing her room in nervous anticipation of Vanderbank's arrival, the narrative states that the friends in her photographs seem 'highly prepared, with small intense faces, each, that 
happened in every case to be turned to the door' (413-14). This is more than playful projection:

The pair of eyes most dilated perhaps was that of old Van, present under a polished glass and in a gilt-edged morocco that spoke out across the room, of Piccadilly and Christmas, visibly widening his gaze at the opening of the door, the announcement of a name by a footman and the entrance of a gentleman remarkably like him save as the resemblance was, on the gentleman's part, flattered (414).

This sequence is reminiscent of Roland Barthes' famous statement that photography is 'the advent of myself as other' ${ }^{27}$ Photographs are, in this sense, inherently flirtatious objects, since they encourage us to see ourselves as we appear to the other. The two versions of Vanderbank highlight the novel's theme of doubling and reproduction, which is particularly important in relation to Nanda, as I will discuss in the following section. The image's main importance, however, lies in its role within a network of exchange. The 'gilt-edged morocco' frame that speaks of 'Piccadilly and Christmas' places the image within a system of commodities and gift-giving. The photograph, which multiplies and homogenises its subjects, operates as what Karl Marx would call a 'universal equivalent' among commodities. In other words, its exchange is necessary to begin a wider exchange of presents, ideas, social visits, and, potentially, conversations, flirtations, and seductions. The photograph's ideological power rests in the fact that while being observed as a single image it may appear to be an aesthetic object outside of the grubby world of exchange, but it is exactly at such festishised moments of intimacy that it operates as a node within a system of commodities. Perhaps a gift from Vanderbank himself, the picture places Nanda within a community. This community, which is both enabled by photography and an enabler of photography, empowers Nanda to give out images of herself in order to build friendships and, eventually, to obtain a suitor. But such social networking leaves her in an unsure position, entangled within a web of 
interconnected desires that tell her that she must coquette in order to obtain a husband, but also that she must maintain a mask of innocence about such worldly matters.

In a photographically-suggestive paradox, Vanderbank, discussing another young woman, declares to Nanda: 'You can't leave anybody with nobody—exposed to everybody' (323). Leaving anybody with nobody and exposed to everybody is a fairly accurate description of photography, if one adopts the Victorian cliché that the camera takes a picture without human help. The balance of Van's jovial witticism, which Nanda either misses or chooses to ignore, indicates that being 'exposed to everybody' is a fearful situation, but one that is matched by being left with nobody — or perhaps being nobody oneself. This expresses the fact that while becoming overexposed might be socially dangerous, as Nanda later finds when Vanderbank rejects her, there is an equal danger of being underexposed - of becoming, in effect, nobody. This oxymoronic suggestion is, of course, partly a fear of social ostracism, but it is also a feature of the novel's representation of identity in a photographically-emergent culture. As I will now go on to discuss, The Awkward Age has a photographic concern for deixical signification. That is to say, the blankness of photographic identity finds its literary counterpart in James.

\section{Becoming Nobody: Photography, Pointing and Identity in The Awkward Age}

'The commodity carte', as Steve Edwards notes, 'fragmented and dismembered the portrait. It translated people into signs and established patterns of equivalence among them'. ${ }^{28}$ By the time that James wrote The Awkward Age, increasingly reliable emulsions and improvements 
in printing had increased the spread of photography, and accelerated the earlier carte's tendency to homogenise its subjects into recognisable patterns of information. This led to an increased concern with human exchangeability. Photography, as Daniel Novak argues, 'turns all of its subjects into analogous figures', while, according to Stuart Burrows, the mass circulation of images 'threatens to render everyone and everything the same'. ${ }^{29}$ Building on these suggestions, I will demonstrate some ways in which James dramatizes anxieties about human equivalence. The Awkward Age parallels photography's radical uncertainty about individual subjecthood, at the same time as seeming to point to specific markers of identity. This is the worrying element of photographic exchange for James, since it suggests an uncontrollable future of tele-flirtations in which subjects make love, in the nineteenth-century sense of the term, across a virtual network with a wide range of people with whom they have no genuine emotional connection, and whose real identity they may not know.

For her part, Nanda has an undecided quality - despite, or perhaps because of, her duplication via photography. The discussion of her image at the novel's opening indicates the extent to which the novel presents her through the discourse of photography, specifically photographic reproduction. In Longdon's mind, she is a reproduction of her grandmother: a woman with whom the older man was deeply in love. Nanda strikes him as an uncanny copy since, while she reproduces her grandmother's looks exactly, she behaves and talks quite differently. Second, her good looks are indeterminable: 'She has no features', according to Vanderbank, while Aggie's mother describes her as being 'any age you like' $(21,206)$. Using a common development term for an unclear picture, Vanderbank states that Nanda's appearance is 'in a fog' (22). While photography's supposed realism has engendered anxieties about the purpose and ultimate use of Nanda's portrait, its inability to fulfil the ideological assumptions of visual realism leads to further questions of identity. 
Nanda's protean appearance results, in part, from her awkward age. Neither a child nor quite yet an adult, she presents a problem for the other characters in knowing how to respond when she is around. Yet the novel's concerns with selfhood go beyond its central character. Longdon, for example, is described as having 'no presence, but...somehow an effect', as if he were his own ghost (5). Sparse in its physical descriptions, the text's dialogic, script-like form undermines Victorian physiognomic certainties. A similar resistance to fixed models of identity emerges both in the way that the text positions its characters and in its ambiguous dialogue. As in many of James' subsequent works, The Awkward Age is austere in its use of proper names: using a plenitude of alternative terms such as 'young lady' and 'fellow guest' (327-28). This distanced approach to his characters blurs them together, much as the interchangeable subjects of photography become indistinct. James also delays naming characters upon their entrance into a room, as when Vanderbank is pondering the propriety of a titillating French novel, wrapped in blue paper, being left on display in the house of another of Nanda's friends, Tishy Grendon:

While so engaged he became aware of something else and, quickly facing about, recognised in the doorway of the room the other figure the glass had just reflected.

'Oh you?', he said with a handshake. 'Mrs. Grendon's down?' (322).

This sequence is itself flirtatious, teasing the reader by holding back the identity of 'the other figure', who turns out to be Nanda, until after Vanderbank has both greeted her and shaken her hand. A rhetorical question, in general conversation 'Oh you?' interpellates its subject, who presumably recognises herself in the appellation and responds accordingly. But here ' $O h$ you?' is also playful, since Vanderbank knows to whom this pronoun refers and the reader 
manifestly does not. The phrase could refer to anybody, being equally applicable to everybody and making distinctions between nobody. It is indiscriminate, much as photography's virtual flirtations are indiscriminate. The scene's oscillation between recognition and mis-recognition, between particularly and interchangability, is highlighted further by the fact that Vanderbank first sees Nanda in the mirror: a reflection that is, like the image produced by photography, both herself and not herself. ${ }^{30}$ This small interaction is indicative of how James uses pronouns, both in this text and in his later writings. Meant to indicate a particular identity, and to be used only when it is clear to whom they refer, in The Awkward Age pronouns delay precise meaning, paralleling flirtation's pleasurable deferral.

The novel's pronoun use, along with its resistance to using identity markers in dialogue, creates a sense of human interchangeability. This is especially the case within Mrs. Brookenham's circle of social gossips, whose witty conversation flows back and forth breathlessly with little indication of who is speaking or being spoken about. The group's conversation, which is always witty, ironic and knowing, causes friction with those who are outside of it. For instance, Mrs. Brook discusses a young woman named Fanny with the MP. Mr. Cashmore, who, as his name suggests, has the values of a boorish capitalist, and who as a result frequently fails to keep up with the banter of her friends: conceive.'

'She wouldn't, in the case you conceive, recognise really the need of what you

Mr. Cashmore wondered — it was almost mystic. 'I don't understand you.'

Mrs. Brook, seeing it all from dim depths, tracked it further and further. 'We've talked her over so!'

Mr. Cashmore groaned as if too conscious of it. 'Indeed we have!'

'I mean we' and it was wonderful how her accent discriminated. 'We've talked you too- but of course we talk every one' (140). 
Mr. Cashmore is here put in his place, positioned outside of Mrs. Brook's inner circle through her correction, italicised for emphasis, of his use of ' $w e$ '. Cashmore's misrecognition of this pronoun indicates his peripheral position as someone who struggles with linguistic uncertainty. His complaint 'I don't understand you' signifies his inability to read the signs, in this case Mrs. Brookenham's ‘what you conceive'. Like a photograph, Mrs. Brook’s determiner ' $w$ hat' seems to be indexical, in the Peirceian sense that it seems to point to or indicate an exact state of affairs, a pointing that is emphasised (once again) by the use of italics. ${ }^{31}$ Yet, also like a photograph, the term resists precise signification, since the reader does not know ' what' Mr. Cashmore conceives any more than he apparently does. Mrs. Brook's 'we' indicates the novel's concern with group consciousness, a networked form of social relation that emerges through conversations that are flirtatious in both their content and their form.

As I have indicated, much of the dialogue in The Awkward Age is ambiguous. ${ }^{32}$ Indeed, the conversation is so circuitous that the characters themselves show signs of frustration. One example is when the young Mr. Mitchett grows angry at Vanderbank for not understanding his suggestion that Vanderbank should be clear to marry Nanda following his own decision to step aside. The business, Mitchett states, is settled:

'But, my dear man, what can Nanda "settle"?'

'My fate,' Mitchy said, pausing well before him.

Vanderbank sat now a minute with raised eyes, catching the indistinctness of his friend's strange expression. 'You're both beyond me!' he exclaimed at last. 'I don't see what you, in particular, gain.'

'I didn't either till she made it all out to me. One sees then, in such a matter, for one's self. And as everything's gain that isn't loss, there was nothing I could lose. It gets me,' Mitchy further explained, 'out of the way.'

'Out of the way of what?' 
This, Mitchy frankly showed, was more difficult to say, but he in time brought it out. 'Well, of appearing to suggest to you that my existence, in a prolonged state of singleness, may ever represent to her any real alternative.'

'But alternative to what?'

'Why, to being your wife, damn you!' Mitchy, on these words turned away, and his companion, in the presence of his renewed dim gyrations, sat for a minute dumb. Before Van had spoken indeed he was back again. 'Excuse my violence, but of course you really see.'

'I'm not pretending anything,' Vanderbank said- 'but a man must understand' (310-11).

Mitchy's annoyance with Vanderbank is understandable, given that the latter is often at the centre of the book's many playful, roundabout conversations. The reason that Van struggles in this scene is because he does not understand Mitchy's motive for stepping aside ('I don't see what you, in particular gain'). Mitchett's anger and refusal to answer are indications of his sexuality: as Van subsequently puts it, 'I can't help it's coming over me then that, on such an extraordinary system, you must also rather like $m e^{\prime}$ (311-12). Mitchy, who is variously referred to in the novel as having 'queer vision', a 'queer countenance', as giving out 'queer condonations' and as being simply 'queer' $(75,94,204,354)$, responds that Van must be used to people liking him, even if such liking is a source of 'sacred terror' which has 'consequences' for people 'who are made as $I$ am' (312). Since this is as close to an admission as he comes, his queerness appears in the classical formulation of a present absence: a love that dare not speak its name. As Richard A. Kaye notes, in the years following the notorious trial of Oscar Wilde, 'flirting with a member of one's own sex becomes a way of suggesting homosexual desire without directly conveying it, toying with same-sex carnal relations without leaving prima facie evidence'. ${ }^{33}$ At other times a conscious disruption of traditional codes of sexual conduct, in this context flirtation is a survival strategy. The danger of photographic flirtation is that it might leave evidence, which in part 
explains James' ambivalent relationship to photography. Yet because flirtation is inherently ambiguous, and as long as it does not become explicit and tip over into seduction, this evidence in fact remains uncertain and, in a sense, inadmissible.

Queerness in The Awkward Age is not limited to Mitchett, since Nanda herself embodies sexual aporia and a form of queerness that may or may not be homosexual. ${ }^{34}$ She admits to Mitchy that she can only love someone who disapproves of her, a situation that can only lead to her being rejected (300). Loving-in-vain, with a flirtatious but ultimately unconsummated passion, is the only love that Nanda can feel truly. In both her queer forwardness and forward queerness, then, Nanda disrupts the Victorian marriage plot, embodying the novel's sense of stalled progress at the fin de siècle. Indeed, each of the central characters, not least Vanderbank and Longdon, provides some form of evidence for a queer reading. This is what David Kurnick means when he suggests that 'The Awkward Age is distinctive...for its refusal to identify sexual perversions with discrete individuals, for its demurral from the idea of interiority in favour of a model of group consciousness' ${ }^{35}$ This consciousness is expressed through the group discussion that dominates the novel, particularly in its blank, deictic style.

The text's central question, as Mitchett puts it to Longdon in reference to the awkwardness of Nanda's knowledge of the adult word, is whether it is possible to 'give it a name', (402). ${ }^{36}$ This 'it' is not sexuality per se, but rather identity rooted in language. To 'give it a name' would close off interpretive possibility, something that the novel refuses to do. In this way, and like many of James' other books, The Awkward Age renders language queer. ${ }^{37}$ The inability or unwillingness of Mrs. Brook and her friends to tie words down to particular meanings explains why Mr Longdon finds the group's conversation frightening (30). For him, the stability of language underpins stable demarcations between borders of class, gender, and sex. At the end of the text, about to assume responsibility for Nanda's 
welfare, and perhaps to make her his wife, he asks her 'when have we talked?' (456). At her surprised suggestion that they have done little else, Longdon responds 'Well, you may have: if that's what you call talking — never saying a word. But I haven't' (456). A scion of an earlier time, Longdon epitomises nostalgia for a simpler era in which, he believes, respectable women did not distribute flirtatious photographs to young men, and conversation managed to achieve a kind of Habermasian ideal. His nostalgia anticipates that of the protagonist of 'Crapy Cornelia' who, as the following section will demonstrate, also experiences a sense of being out of time: a feeling which is embodied by the act of looking at an old photograph.

Networks and photographic difference in 'Crapy Cornelia'

For James, photography was a source of concern because of the virtual networks it could create and the effect of those networks upon human relationships and notions of identity. Yet he also saw it as a changeable form. Towards the end of his career, as photographic technologies were consolidated in various ways for the consumer marketplace, James differentiated between older and newer photographies on the basis of their distinct social effects. His late short story 'Crapy Cornelia' shows a nostalgic preference for the photography of the 1860s, an era of more intimate and discriminate image reproduction, over more modern, instantaneous technologies. In this story, old photographs are metonymic of broader social changes.

'Crapy Cornelia' positions photography as enabling networks of flirtation between the living and the dead. James' protagonist, White-Mason, a man of advancing years, visits New York after a long absence, as James himself had done in the early twentieth century. He tries 
to get up the courage to propose marriage to a younger and more modern woman, Mrs. Worthington. As so often in James, this proposal is endlessly deferred. White-Mason is first put off from proposing in Mrs. Worthington's drawing room by the re-appearance of an old friend, Cornelia Ranch. He determines to propose once again, but later decides against this course of action after seeing a carte-de-visite of a former love-interest, the long-dead Mary Cardew, in Cornelia's house. In part, this image represents nostalgia for his earlier, more passionate feelings. It also represents nostalgia for an earlier form of photography: the cartede-visite itself. As I have written elsewhere, it is important to attend to technological specificity when examining representations of photography in nineteenth and early twentiethcentury literature. ${ }^{38}$ And James was certainly conscious of differences between early twentieth-century photography and that of his youth. As he wrote in 'Edmond Rostand' (1901), 'so many other modern conveniences have become indispensable...new machinery supersedes old, the kodak displaces the camera. They represent the portable, and the portable now is everything, ${ }^{39}$ The surprising, even overblown, contrast that James draws here between the 'kodak' and the 'camera', presumably the collodion method, indicates his awareness that photography is not one technology but many. In his conservative rendering, there is a sense of loss in the move to 'modern conveniences'. Contemporary society, he suggests, privileges ease and portability over more substantive and gradually-achieved qualities.

Similarly, in 'Crapy Cornelia', the carte's difference from the Kodak is emblematic of the distinction that White-Mason draws between himself and Mrs. Worthington's 'high modernity', a modernity that he perceives everywhere upon his arrival in New York. ${ }^{40}$ Like Mr. Longdon in The Awkward Age, White-Mason is disturbed by the twentieth century's changing sexual and social mores. Constantly checking his watch, he is troubled by the passing of time. His sense of being stuck in the wrong era is expressed in photographic 
language. Upon entering Mrs. Worthington's house, he quickly takes in his surroundings, noticing the 'standing newness of everything about him', which appears to have 'that gloss of new money' (193):

This could but be yet more the case for the impression of the observer introduced and committed. On our friend's part, I mean, after his admission and while still in the hall, the sense of the general shining immediacy, of the still unhushed clamour of the shock, was perhaps stronger than he had ever known it...

He met the whole vision with something of the grimace produced on persons without goggles by the passage from a shelter to a blinding light; and if he had - by a perfectly possible chance - been "snap-shotted" on the spot, would have struck you as showing for his first tribute to the temple of Mrs. Worthington's charming presence a scowl almost of anguish (194).

White-Mason's mental image produces an impression of glossy newness, of a shining surface appearance that he associates with present-day America. Immediately after this section, the narrator notes that White-Mason is in the habit of shielding his eyes from bright lights, which left him 'bleeding, blinded, from the riot of the raw - or, to put the whole experience more prettily, no doubt, from excess of light' $(195-96) .{ }^{41}$ His literal and mental visioning power is insufficient for the modernity of New York and Mrs. Worthington. But photography in the sequence just quoted does not work one-way. As well as White-Mason's own instantaneous thought, the narrator imagines the impression that he would make if 'snap-shotted' at that exact moment. That this is 'a perfectly possible chance' indicates the narrator's wry attitude towards the coming-into-being of photographic ubiquity. Instant photography, crucially, does not allow the subject time to erect a defence against the world, 'To prepare a face to meet the faces that you meet', as T.S. Eliot's Prufrock would put it only five years later.

In contrast, Cornelia Ranch's carte-de-visites, including the picture of Mary Cardew, possess 'the tone of time, the secret for warding and easing off the perpetual imminent ache 
of one's protective scowl' (223). These faded, 'sallow' images are soft, intimate objects; they have a longer exposure time to encourage the subject to relax. ${ }^{42}$ It is important for WhiteMason to touch Mary Cardew's photograph; he holds it behind him as if 'the very feel of it, pressed against him, was good to his palm' (224). The image allows him a historical-anterior intimacy with Mary. The picture creates a network of connection: as White-Mason states to Cornelia, 'You connect me with it. You connect it with me' (228). This imaginative network spans time, allowing Mary and White-Mason, in his mind at least, to continue their interrupted relationship. Mary's eyes accuse him of not having been fair to her, presumably because he did not marry her: 'Oh her charming, sad eyes and the way they say that, across the years, straight into mine!' (231). By exploiting memory and desire, the dead can speak (or be imaged to speak) to the living. White-Mason agrees to exchange the picture for another that he possesses, one which does not show Mary's 'lovely head' quite as well. He wishes for an image that will allow him to look directly into Mary's eyes, as if that would bring him back into communication with her. Though his actions could be problematized in several ways, 'Crapy Cornelia' is complicit in White-Mason's nostalgic imagining of carte-de-visite photography. Like The Awkward Age, the story concludes with a man possessing an image of a young girl. In this case, however, the narrative implies a more affective purpose. Described as a 'small relic', Mary's image becomes a kind of a secular Icon (232). White-Mason folds it 'with deliberation' into his pocket book, placing it inside his coat, close to his heart (232). The difference between the type of relationship in these texts, one (primarily) sexual and the other (primarily) devotional, is based upon the difference that James perceives between the modern photography of The Awkward Age and the nostalgic cartes of 'Crapy Cornelia'.

\section{$\underline{\text { Conclusion }}$}


The photographic complex is a widespread but neglected aspect of long nineteenth-century fiction. Future research might examine visual networks in texts by Margaret Oliphant, Cuthbert Bede (Edward Bradley), Thomas Hardy, Arthur Conan Doyle, Frederick Douglass, Amy Levy, Anthony Trollope, and numerous other writers in whose work photography makes a significant appearance. As this article has shown, Henry James represented photography as an enabler of virtual, networked relationships. He portrayed late nineteenthand early twentieth-century photography as marking, if not indeed causing, a change in social mores. Since it was now possible to imagine a future in which photography would be ubiquitous, writers often took the technology to logical extremes in their work. In The Awkward Age, Nanda's photograph is central to a narrative that is both suspicious of and drawn to the more relaxed relations between men and women that predominate in Mrs Brookenham's drawing room. In this text, individual identity matters less than the web of relations between people. A networked consciousness emerges through his abstruse style, in frequent delays or deferrals of meaning. In 'Crapy Cornelia', James nuanced his portrayal of photography through a comparison of different technologies: critiquing the 'high modernity' of the Kodak while romanticising the carte-de-visite as a slower and more meaningful type of photography.

In a twenty-first century world of webcams, sexting and revenge pornography, many of the issues discussed in this article will seem familiar. Like our forebears, we struggle to cope with the networks created, and the connections made possible, by modern teletechnologies. Flirtation, I will end by suggesting, provides an appropriate model for using webs of visual information. We should be interested, but not over-committed; energised by proximity, but not swept off our feet; attracted, but not seduced. This is where the Victorians, our own intimate strangers, might be of some help. Having created a networked grid of imaged relations, they were the first to live with distanced proximity. We can learn as much 
from their overcompensations and exaggerations, which are abundant in the literary record, as we can from their more sober, scientific pronouncements. Victorian Literature provides us with numerous examples of how human beings might play with, be enticed by, and, where necessary, resist virtual networks.

My sincere thanks to Ruth Charnock, Pamela Thurshwell, and Rebecca Styler for their invaluable feedback on this article.

Email for correspondence: oclayton@lincoln.ac.uk

${ }^{1}$ - There are many other examples. In H. Rider Haggard's Mr Meeson's Will (1888), for instance, a young writer called Augusta Smithers has a will tattooed upon her neck, following a ship wreck in which she is the only survivor. Representing a change of heart by the titular Mr Meeson, who had previously disinherited his nephew, Eustace Meeson, Augusta's neck becomes evidence (an index of an index, we might say) in a legal dispute between the nephew and Mr. Meeson's wider family. Seeing the difficulty of filing her neck in a Registry Office drawer, Eustace's lawyers order a photograph to be taken instead. Eustace is later shocked to discover images of Augusta's bare neck being sold all over London. H. Rider Haggard, Mr Meeson's Will, London: Longman's, Green and Co. 1894.

${ }^{2}$ - I use the term 'exchange' to mean more than simply images being swapped. The images under discussion may be bartered, stolen, swapped or sold, but in each case they enter a public realm of commodity goods. Already within a network of objects, these goods then engender, as this article will discuss, further social networks between people.

3 - Sharon Cameron, Thinking in Henry James, Chicago: University of Chicago Press, 1989, 77. 
${ }^{4}$ - Photography was not the only technology that caught James' interest on the grounds of being able to create connections between people over large distances. Telegraphy was another prominent example. See Mark Goble, Beautiful Circuits: Modernism and the Mediated Life, New York: Columbia University Press, 2010, 23-84.

5 - Julie Grossman, “ "It's the Real Thing”: Henry James, Photography, and The Golden Bowl' in The Henry James Review, 15:3 (Autumn 1994), 310.

${ }^{6}$ - Laura Saltz, 'Henry James's Overexposures' in The Henry James Review 25:3 (Autumn 2004), 256-63.

${ }^{7}$ - See, for example, James Firebaugh, 'Henry James's Photographer' in American Quarterly 7:3 (Autumn 1955), 213-33; Adam Sonstegard, 'Painting, Photography, and Fidelity in The Tragic Muse' in The Henry James Review 24:1 (Winter 2003), 27-44; Melanie Ross, " "The Mirror with a Memory": Tracking Consciousness in the Preface to The Golden Bowl' in The Henry James Review 26:3 (Autumn 2005), 246-55.

${ }^{8}$ - Ralph F. Borgardus, 'The Photographer's Eye: Henry James and the American Scene' in History of Photography: an International Quarterly 8:3 (July 1984), 180.

${ }^{9}$ - Literary scholarship has tended to privilege modernism when analysing depictions of photography. For more, see Owen Clayton 'Barthes for Barthes' Sake? Victorian Literature and Photography beyond Poststructuralism' in Literature Compass 13:4. 245-257.

${ }^{10}$ - See, among others, Edward L. Schwarzchild, ‘Revising Vulnerability: Henry James’s Confrontation with Photography'. Texas Studies of Literature and Language 38:1 (Spring 1996): 51-78; Wendy Graham, 'Pictures for Texts' in The Henry James Review 24:1 (Winter 2003): 1-26; Stuart Burrows, A Familiar Strangeness: American Fiction and the Language of Photography, 1839-1945, Athens, Georgia: The University of Georgia Press, 2010.

11 - Fred Kaplan, Henry James, the Imagination of Genius: a Biography, New York: William Morrow and Company, 1992, 513. 
12 - Henry James to Hendrik C. Anderson, $31^{\text {st }}$ May 1906, in The Letters of Henry James Vol

4, ed. Leon Edel, Cambridge, Mass; London, England: The Belknap of Harvard University Press, 1984, 406.

13 - Sigmund Freud, 'Thoughts for the Times on War and Death' in The Standard Edition of the Psychoanalytical Works of Sigmund Freud, Vol 14, trans and ed. James Strachey, London: Hogarth Press, 1981, 291.

14 - See Georg Simmel, 'Flirtation' (1909/1923) in Women, Sexuality and Love, trans and ed.

Guy Oakes, New Haven and London: Yale University Press, 1984, 133-52.

15 - Ibid., 144.

16 - Adam Phillips, On Flirting, London; Boston: Faber and Faber, 1994, xvii-xix.

17 - Paul Fleming, 'The Art of Flirtation: Simmel's Coquetry without End' in Flirtations:

Rhetoric and Aesthetics this Side of Seduction, ed. Daniel Hoffman-Schwartz, Barbara

Natalie Nagel, and Lauren Shizuko Stone, New York: Fordham University Press, 2015, 22 -

24.

18 - Henry James, 'Four Meetings’ (1879/1909) in Selected Stories, London: Oxford

University Press, 1957, 2. Subsequent references to this text will be given in the body of the article.

19 - 'Making love' in the nineteenth-century meant 'to pay amorous attention', rather than the act of sexual intercourse. See the Oxford English Dictionary entry on love.

${ }^{20}$ - The first commercial use of a focal plane shutter, which might be said to produce the 'jog’ of which James speaks, was the 1890 Anschütz Camera. See Colin Harding, Classic Cameras, Lewes, UK: Photographers' Institute Press, 2009, 80-81. James probably has the Kodak in mind.

${ }^{21}$ - Patrizia Di Bello, Women's Albums and Photograph in Victorian England: Ladies, Mothers, and Flirts, Aldershot: Ashgate, 2007, 130. 
${ }^{22}$ - It is important to note that photography takes many forms in James' work, although, as in The Awkward Age, it generally concentrates around issues of sex and control. In The Golden Bowl (1904), for example, photography represents a sexual past from which the protagonist Prince Amerigo cannot escape. His affair with Charlotte Stant is uncovered by a shop-owner who recognises their photographs. This is foreshadowed early on in the novel when the inescapability of the Prince's history, as well as the inexorability of his racial heritage, is described as being akin to a bath in which he sinks up to his neck: 'the hair of his head, might have been steeped as in some chemical bath'. Henry James, The Golden Bowl, London: Penguin, 2009, 36. Elsewhere, James connects photography to a growing culture of celebrity and commodity exchange. In The Bostonians (1886), for instance, Verena Tarrant sells her image to photography shops in order to promote both her political cause and her own fame. ${ }^{23}$ - Henry James, The Awkward Age: a Novel, New York and London: Harper \& Brothers Publishers, 1899, 14-15. Subsequent references to this text will be given in the body of the article.

24 - Susan Mizruchi, 'Reproducing Women in the Awkward Age' in Representations 38:1 (Spring 1992), 120; Michèle Mendelssohn, “'I'm not a bit expensive”: Henry James and the Sexualization of the Victorian Girl' in Nineteenth-Century Childhood and the Rise of Consumer Culture, ed. Dennis Denisoff, Aldershot, UK: Ashgate, 2008, 88.

25 - Mrs. Brookenham uses the term, which may have originated with Vanderbank, to describe the inappropriate 'blue' French novel that Nanda is discovered to have read. 26 - Pamela Thurschwell, 'Bringing Nanda forward, or acting your age in The Awkward Age' in Critical Quarterly 58:2 (July 2016), 81.

27 - Roland Barthes, Camera Lucida: Reflections on Photography. trans. Richard Howard, London: Vintage, 2000, 12. 
28 - Steve Edwards, The Making of English Photography: allegories, University Park, Pennsylvania: The Pennsylvania State University Press, 2006, 81.

${ }^{29}$ - Daniel Novak, Realism, Photography and Nineteenth Century Fiction, Cambridge: Cambridge University Press, 2008, 38; Burrows, 74.

${ }^{30}$ - James would have been familiar with Oliver Wendell Holmes' famous reference to photography as 'a mirror with a memory'. Oliver Wendell Holmes, 'The Stereoscope and the Stereograph' (1859) in Classic Essays on Photography, ed Alan Trachtenberg, New Haven, Conn: Leete’s Island Books, 1980, 74.

31 - C.S. Peirce would call this term a 'designator', a type of index which contains, according to Martin Lefebvre, an 'indirect indexical relation' to its signified. That is to say, it both points at its object and is indirectly caused by that object. See Martin Lefebvre, 'The Art of Pointing: On Pierce, Indexicality, and Photographic Images' in Photography Theory, ed. James Elkins, New York and London: Routledge: 2007, 231.

32 - While Nanda might adopt what Matthew Krumholtz calls 'straight talk', this is drowned out by the indirect speech of other characters to such a degree that it remains both a 'minor style' and 'the style of a minor'. Matthew Krumholtz, 'Henry James's Straight Talking Style' in Henry James Review 35:3 (Autumn 2014), 233.

33 - Richard A. Kaye, The Flirt's Tragedy: Desire without End in Victorian and Edwardian Fiction, Charlottesville and London: University Press of Virginia, 2002, 179.

${ }^{34}$ - For more on Nanda's sexuality, see Alan M. Nadel, 'What Nanda Knew: A Truth not Universally Acknowledged in The Awkward Age' in Transforming Henry James, ed. Anna De Biasio, Anna Despotopoulou, Cambridge: Cambridge Scholars, 2013, 226-41. 35 - David Kurnick, Empty Houses: Theatrical Failure and the Novel, Princeton, New Jersey: Princeton University Press, 2012, 130. 
${ }^{36}$ - Scholars have noted James' repetitive, even obsessive, use of 'it' to refer to both objects and ideas. In Slavoj Žižek's Lacanian reading of James, this 'it' is a repressed object of desire. For Seymour Chapman, " "it" is one of many deictic utterances that show James' interest in words that point rather than represent'. Exactly what is being pointed to in James is, however, less certain than both of these readings suggest. See Slavoj Žižek, Lacan: The Silent Partners, London: Verso, 2006, 299 \& Seymour Chapman, The Later Style of Henry James, Oxford: Blackwell, 1972, 54.

37 - For more on this, see Kevin Ohi's excellent Henry James and the Queerness of Style, Minneapolis: University of Minnesota Press, 2011.

38 - See Owen Clayton, Literature and Photography in Transition, 1850-1915, Basingstoke, Hampshire: Routledge, 2015.

39 - Henry James, 'Edmond Rostand' (1901) in Essays on Art and Drama, ed. Peter Rawlings, Aldershot: Scholar, 1996, 524-25.

${ }^{40}$ - Henry James, 'Crapy Cornelia' (1909) in The Finer Grain, New York: Charles Scribner's Sons, 1910, 199. Subsequent references to this text will be given in the body of the article. ${ }^{41}$ - On James and impressionism in the context of painting, see Daniel Hannah, Henry James, Impressionism and the Public. Burlington, VT; Farnham, UK: Ashgate, 2013. ${ }^{42}$ - This nostalgic representation of early photography is somewhat at odds with the experience of historical subjects. Ralph Waldo Emerson, for example, described having to keep still for a daguerreotypist in these terms: 'hands...clenched as for fight or despair...the brows contracted into a Tartarean frown, and the eyes fixed as (only) they are fixed in fits, in madness, or in death'. Ralph Waldo Emerson, Journals and Miscellaneous Notebooks (1841), Cambridge, Mass: Belknap Press of Harvard University Press, 1960-1982, Volume VIII, 115116. 